\title{
BISHOP DIXON, THE IRISH HISTORIAN AND IRISH LAW
}

\section{Niall Osborough, School of Law, University College Dublin}

The writing of history can be likened to the doing of a jigsaw puzzle. The more pieces are assembled the more coherent the shape of the final picture. And one would be ill-advised to imagine that the final picture can satisfactorily emerge without each and every one of the available pieces being properly slotted in. Finding the pieces when they do not tumble out freely and comprehensively from the box in which the jigsaw has been secreted serves naturally even so to distinguish the process of writing history from the doing of a jigsaw puzzle. Here the search for pieces to complete the historical puzzle risks at times to become a life-time burden.

To be sure, the more pieces of evidence one can turn up the more convincing and therefore the more instructive the interpretation of what has been the focus of the investigation. In the process, mysteries from time to time can quite confidently be laid to rest. Take, for instance, the case of Bishop Richard Dixon, appointed to the Church of Ireland see of Cork in 1570.

In the succession list of bishops in Cork furnished by Archdeacon Henry Cotton in the volume for Munster in his Fasti Ecclesiae Hibernicae published in 1847, there appears this entry against the year $1570:^{1}$

"Richard Dixon, Prebendary of Rathmichael in St. Patrick's Cathedral, Dublin, was appointed bishop by patent dated June $6^{\text {th }} .{ }^{\prime 2}$

The entry concludes with this further slightly sinister notice:

"He was deprived in the following year, for some cause now unknown."

Thus is a conundrum presented: why was Bishop Dixon removed from his post in 1571 ?

In 1854 , in the first volume of his three-volume history of Dublin, John Gilbert solved the conundrum. ${ }^{3}$ Dixon had been deprived of his see 'propter adulterium manifestum per eum commissum et confessum'. The evidence was furnished by an order made on 7 March 1570 by the then Commissioners for Ecclesiastical Causes which prescribed the penance Dixon was obliged to undergo. (The background to the deprivation, Gilbert

1 Henry Cotton, Fasti Ecclesiae Hibernicae: the succession of the prelates and members of the cathedral bodies in Ireland - vol. 1: the province of Munster (Dublin, 1847), p.182.

2 In a second edition of this volume of the Fasti Ecclesiae Hibernicae Cotton adds the detail that Dixon was consecrated before the end of the year 1570, but repeats the assertion that the cause of Dixon's being deprived remained unknown: Fasti Ecclesiae Hibernicae - vol. 1: the province of Munster, $2^{\text {nd }}$ ed. (Dublin, 1851), p.222.

3 John T. Gilbert, A history of the city of Dublin, 3 vols. (Dublin, 1854 - 1859), i, $113-114$. 
noted, constituted 'a fact unnoticed by our ecclesiastical historians'.) Since the source Gilbert quotes from is no longer extant, the punishment meted out to Dixon merits being rehearsed: ${ }^{4}$

"That upon Sondaie next immediatlie following into the cathedral churche of the blessed Trynitie in Dublin the said Bishop shall come even at such tyme as the preacher shall goe up into the pulpitte to preache, with a white rodde in his hand and so bareheaded shall goe up into another lower pulpitte sett there for the same purpose and there stand during the whole time of the sermon and after that the preacher shall make an end the said Bishop shall there openlie confesse his faulte and desire forgevenes of God and the people to pray for him and immediatelie after that, in the same place he himself shall utter somewhat touching the grevousness of his owne faulte and showe his repentence therefor and desire forgevenes openlie of God and all ye people to pray for him and to forgyve him whom he hath by comitting of the same offended, and all the premisses in the most penitent maner he can doe."

Seven years elapsed between Cotton's announcement of the puzzle and Gilbert's declaration of that puzzle's solution. Six years after volume 1 of Gilbert's history of Dublin had appeared, H.C. Hamilton's edition of the Calendar of State Papers relating to Ireland, 1509 to 1573 was published. This confirmed Gilbert's discovery and went into rather more detail about Dixon. He had been, it would appear, chaplain to the lord deputy, Sir Henry Sydney. ${ }^{5}$ In pressing for Dixon's appointment on 26 December 1569, Sydney was to point out that the value of the bishopric to which he trusted his protégé would be appointed - technically the bishopric of the combined sees of Cork and Cloyne - would not be likely to exceed $£ 40$ annually. By the spring of 1571, the trust in Dixon had been found to be misplaced. On 16 April, Robert Weston, the Irish chancellor, Adam Loftus, the archbishop of Dublin and Lord Justice Fitzwilliam joined in a report to Burghley in London that Dixon, despite being a married man, had 'under colour of matrimony, retained a woman of suspected life as his wife.' ${ }^{6}$ Dixon had been compelled to do penance in Christ Church cathedral - by the terms of the decree Gilbert reproduces - but 'fearing to exceed their commission' the authors of the letter desire that Burghley would send them advice on how to proceed over depriving the bishop.

4 ibid., 114. Gilbert quotes two other similar orders of the Commissioners for Ecclesiastical Causes: in the cases of Henry Hinchcliffe and Constance Kyng, an order of 29 March 1571 (ibid., pp.213-215); and in the cases George Bateman and Benedicta his kept woman (meretrix), an order of 30 October 1572 (ibid., p.215). Prior to the destruction of public records in 1922 the Irish Public Record Office held the Registrar's Book containing the acts of the Commissioners for Ecclesiastical Causes appointed in 1568. This book covered the years 1570 to 1573, and is almost certainly the source quoted from by Gilbert. See Herbert Wood, A guide to the records deposited in the Public Record Office in Ireland (Dublin 1919), p.267.

5 Cal. S. P. Ire., $1509-1573$, p.424.

6 Cal. S. P. Ire., $1509-1573$, p.444. 
Certainly by 26 November 1571 Dixon had been deprived, for on that date the name of the proposed replacement as bishop of Cork was forwarded to Burghley in separate communications of that date from both the archbishop of Dublin and Lord Justice Fitzwilliam. ${ }^{7}$

The re-calendaring of the State Papers Ireland for the years $1571-1575$, in the volume edited by Mary O'Dowd and published in 2000, yields a considerable amount of additional information. The full text of the letter to Burghley sent on 16 April 1571 reveals that Dixon's conduct came to the attention of the authorities in Dublin 'by public fame and crying out of his deed'. ${ }^{8}$ His conduct constituted 'no little glory of the adversaries and the grief of the godly ${ }^{\prime 9}$ which had determined the course of action pursued in Dublin. Of Dixon's acknowledgment of his offence Burghley's correspondents observed that it was 'not in such penitent sort as we thought meet to put away the offence of so grievous and public a crime'. ${ }^{10}$

On the vexed question as to whether the Dublin triumvirate had the power to deprive Dixon - this might have encroached, they argued, on the queen's authority - they went on to seek guidance from Burghley, just as the much shorter entry in the original Calendar for the years 1509 - 1573 had indicated. The full entry in the new Calendar deals with the point, and is of particular interest: ${ }^{11}$

"And having no great trust in the learning or in the sincerity of the consciences of the lawyers here nor any other, we thought we might resort to you for help. Our request is that you might upon conference had with learned and godly lawyers write to us what we may do therein. We enclose a copy of the relevant clauses in our warrant. ${ }^{12}$ And if it shall be resolved clearly that by virtue of our commission we cannot deal therein, yet for that the public slander does remain still and in this slanderous and perverse people cannot but continue during such time as he shall remain in the bishopric, we would ask you to appoint a private commission to such as may please the queen that he may be removed from the bishopric."

Burghley's response does not appear to be extant, but it would seem he gave Weston, Loftus and Fitzwilliam the 'green light' to press ahead and deprive Dixon without further ado. Deprivation is dated to 8 November $1571 .^{13}$

My business here is to draw attention to one species of evidence which, unlike the material unearthed by Gilbert and his successors in the case of Bishop Dixon, does not necessarily help solve a riddle, but which nevertheless fills out the context and thus advances the understanding. I allude to legal source-material and, in particular, material to be gleaned from

7 Cal. S. P. Ire., $1509-1573$, p.460.

8 Calendar of State Papers, Ireland: Tudor Period, 1571 - 1575, ed. Mary O'Dowd (London and Dublin, 2000), p.11.

9 ibid.

10 ibid.

11 ibid., p.12

12 Printed, ibid.

13 As per the index, ibid., p.907. 
the law reports - a source of enlightenment, I venture to suggest, not too frequently opened by the Irish historian.

Let me therefore produce a short inventory of opportunities let slip as a result of the reluctance of the Irish historian to engage with such legal material.

The most egregious omission of a pertinent legal source in recent Irish historiography will be found in L.P Curtis, Jr's outstanding text on the political governance of late nineteenth-century Ireland. ${ }^{14}$ On 19 August 1886 a start was made with the planned evictions on the Woodford estate of the marquis of Clanricarde in east Co. Galway. The scene is described by Curtis. Two resident magistrates, 500 officers and men of the Royal Irish Constabulary and an assortment of bailiffs and emergency men were all in attendance. 'The resultant operation', Curtis writes: ${ }^{15}$

"which in design and execution resembled a medieval siege cost the authorities some $£ 3000$ and gave Dublin Castle formal notice of what difficulties lay ahead."

And indeed they did.

At the time government policy was aimed at dissuading landlords like Clanricarde from exercising their right to evict. To this end, special orders had been issued for the morning of 19 August. Under these, the police had been instructed not to intervene once the evictions had commenced unless after one hour intervention was essential to preserve the peace.

It was these instructions which were assailed by Chief Baron Palles at the ensuing Connacht winter assizes where a number of individuals faced charges of riot and conspiracy - a sequel not alluded to by Curtis. Palles's observations on the entire sorry episode, including, in effect, criticism of Hicks-Beach, the Irish chief secretary, are preserved in a collection of judgments of the Irish courts during the period of the Land War and designated Judgments of the superior courts. ${ }^{16}$

In January 1887, at the assizes being held in Sligo, Palles first described the sequence of events at Woodford on the critical morning of the preceding August: ${ }^{17}$

"For one whole hour breaches of the peace, in gross and open violation of the law in contempt of the authority of the Queen, and of her mandate to the sheriff were persisted in, in the presence of that strong force of constabulary, and they did nothing. Upon, as I understand it, the conclusion of that period, orders were given to them by the resident magistrates, and the moment that these orders were given they performed their duty, not only with promptitude and courage which cannot be too highly commended, but with a remarkable amount of patience and forebearance, clearly evidenced by the fact that of

14 L.P. Curtis, Jr., Coercion and conciliation in Ireland, 1880 - 1892: a study in conservative unionism (Princeton, N.J., 1963).

15 ibid., p.139.

16 'Observations of Palles CB at the Connacht winter assizes, 5 Jan. 1887', in Judgments of the superior courts in Ireland, $2^{\text {nd }}$ ed. (Dublin, 1890), p.23.

17 ibid., p.24. 
the several thousands constituting the riotous mobs, upon the occasions in question there is no suggestion that injury was suffered by one."

Palles then proceeded to excoriate the Dublin Castle authorities for illegally withholding support for the execution of judicially-sanctioned decrees. ${ }^{18}$ 'When judgment is once given', the chief baron declaimed:

" - the judgement of a court of law, acting within the scope of its jurisdiction - it is not competent to any one in this Kingdom, I care not how high he may be, to say that a writ regularly issued on foot of that judgment shall not be executed, or prevent those who by law are bound to aid in its execution from giving that aid and assistance which the Constitution requires."

Whilst Curtis does not allude to this unprecedented judicial rebuke, the volume of $A$ new history of Ireland devoted to an Irish history chronology makes appropriate amends. In volume 8 of $A$ new history we read under the date line of 5 January 1887: ${ }^{19}$

"Christopher Palles, lord chief baron of exchequer presiding at Sligo winter assizes, rebukes executive government for illegally withholding support from sheriffs executing writs." 20

Two episodes occurring over twenty years earlier - one a traffic accident, the other a fire at a third-level institution - also merit a place in this inventory.

The first was an accident involving a horse-drawn omnibus in which five, or according to another account, six people perished. It occurred in Dublin on 6 April 1861. The accident itself is well-known, being recalled, for example, in an article by Francis Murphy in the Dublin Historical Record. ${ }^{21}$ I have also referred to it myself. ${ }^{22}$ Neither Murphy nor myself mention the circumstance that the accident provoked a lawsuit which was to find its way into the law reports. ${ }^{23}$ The circumstances were, to say the least, unusual: the victims all drowned. The omnibus served the route from Nelson's Pillar to Rathgar on the south side of the city. For some reason not subsequently clarified, the horses at the front of the omnibus encountered particular difficulty in mounting the one major obstacle on the route - the steep slope on Portobello bridge over the Grand Canal. The driver's strategy in resolving the problem was unwise. He set his horses at an angle but, still struggling, they went backwards and precipitated themselves together with the omnibus

18 ibid., p.30.

19 A new history of Ireland: vol. 8 - a chronology of Irish history to 1976, ed. T.W. Moody, F.X. Martin and F.J. Byrne (Oxford, 1982), p.361.

20 See further V.T.H. Delany, Christopher Palles, lord chief baron of her majesty's court of Exchequer in Ireland, 1874 - 1916 (Dublin, 1960), pp.100-104; W.N. Osborough, 'Executive failure to enforce judicial decrees', in J. F. McEldowney and Paul O'Higgins (ed.), The common law tradition: essays in Irish legal history (Dublin, 1990), p.85.

21 'Dublin trams 1872 - 1959', (1979) 33 Dublin Historical Record 2.

22 Osborough 'Recollection of things past: trams, their clientele and the law' (1995) 46 N.I.L.Q. 443 , at $449-50$.

23 Byrne v. Wilson (1865) 15 I.C.L.R. 332. The case was decided by the court of Queen's Bench in Trinity term 1862. 
and its passengers into the adjacent canal lock. Summoned, the lock-keeper in the emergency that had arisen, decided on a course of action, which, in the opinion of certain observers, only made matters a good deal worse. He let more water into the canal, as a result of which a number of passengers, including a Mrs. Mary Byrne, we are told, were 'suffocated and drowned`.

An action under Lord Campbell's Act ${ }^{24}$ was commenced in the court of Queen's Bench by Mary's husband and administrator, William Byrne. He sued Wilson, the proprietor of the omnibus, for an act of negligence which had resulted in the death of his wife in the canal lock. From the account of Byrne v Wilson in the law reports, we can read that, perhaps predictably, Wilson had sought to shift the blame for what had happened on to the shoulders of the lock-keeper. He was not responsible, he argued, for the act of a third party not authorised by him, a third party who was neither employed by him nor under his control. After the bus had landed in the water it was this third party who had effectively occasioned the deaths by wilfully letting the excess water into the canal.

This defence was met by the plaintiff's replication that even if all this was so, the entering of the bus into the canal had materially contributed to the disaster. To this replication, Wilson entered his demurrer, and sought to support this by pressing the argument that no manslaughter charge could conceivably have been brought against him in the light of what had happened.

The Queen's Bench unanimously overruled the demurrer and thus paved the way for Byrne's eventual victory in the case, the details of which remain to be discovered. Chief Justice Lefroy cited Scott v Shepherd, ${ }^{25}$ a leading authority on the responsibility of persons for the direct consequences of their acts. O'Brien J. and Hayes J. agreed, the latter holding that the party guilty of the first act of trespass or neglect had to be held responsible for all that act's natural consequences and results. That followed even though the lock-keeper had raised the sluices unlawfully and inundated everyone trapped in the canal lock.

The fire that broke out at dawn on Thursday 15 May 1862 gutted the west wing of the new Queen's College in Cork (today's University College, Cork). Lord Macaulay in his History of England praised the architectural merit of the building itself ${ }^{26}$ : it was 'worthy', he said, 'to stand in the High Street of Oxford'. The destruction wrought was thus considered at the time a tragedy of no mean proportions. Aside from the physical damage done to the building, the College's herbarium was destroyed as was the Pathology museum. Professors Rushton and Vericour lost manuscripts and Professor Lewis his collection of antique medals, bronzes and shields as well as a valuable casket containing ancient gems.

249 \& 10 Vict., c. 93.

25 (1773) 2 W. B1. 892, 96 Eng. Rep. 525; 3 Wils. 403, 95 Eng. Rep. 1124.

26 Lord Macaulay, History of England from the accession of James II, 5 vols. (London, 1858 - 61), iii, 171. 
Professor Murphy is right to term the story of the fire and its aftermath 'a dramatically lurid episode' in the history of the College. ${ }^{27}$ It was certainly an embarrassment to Sir Robert Kane, the president of the College - its first - a post he held until his retirement in 1873. As it happened, Kane had been one of the first on the scene, but helpless in face of the blaze that had already taken a very firm hold. It was generally agreed at the time that the fire had been started deliberately, but no one was ever charged with arson. As might have been anticipated, the incident inspired 'a number of conspiracy theories, ranging', Murphy would have us believe, 'from the probable to the bizarre' ${ }^{28}$ Relationships within the young College were plainly not of the best when the Professor of Surgery, Denis Brenan Bullen, pointed the finger of suspicion at the President, Kane himself. (The charge was unsubstantiated and Bullen was to be removed from office in 1864.) Another theory was that the fire had been started so as to destroy forensic evidence linked to one or more murder cases being kept at the time in the west wing. A third explanation alluded to the earlier campaign of the priests against 'the godless colleges'; under their influence, it was contended, ultramontane zealots had torched the college.

Within a few days of the fire a poster was circulated offering a reward of $£ 150$ from the College, as well as one of $£ 100$ from the government for information leading to the discovery of the culprit and his conviction. The fire itself was featured in the issue of the Illustrated London News for 24 May 1862.

A protracted struggle to secure compensation under the malicious injuries code forms part of the aftermath as well. Professor Murphy does not enter into the detail, being content to report that in the late summer of 1862 compensation had been refused on the technical grounds that both the College and the Board of Works had failed to post up notices of their claim, as required by law, in the usual places around Cork city. ${ }^{29}$

Very much more information bearing on the eventual loss of this significant malicious injuries compensation claim is to be gleaned from the law report of the proceedings in the court of Queen's Bench generated by the first dismissal of the claim. ${ }^{30}$ In these proceedings significant doctrinal matters were touched on when the court of Queen's Bench took some pains to stress that the statutory requirements on serving notices of any claims were important and were not to be ignored. These requirements were set out in section 135 of the relevant legislation - the Grand Jury (Ireland) Act of $1836 .{ }^{31}$

This prescribed that the applicant-victim of any malicious injury was within 6 days of the occurrence of the injury to:

"serve notice in writing of such injury ... upon the headconstable of the barony and the churchwardens of the parish, and at the nearest police station; or, if there be no

27 John A. Murphy, The College: a history of Queen's / University College Cork, 1845 - 1995 (Cork, 1995), pp.82-94.

28 ibid., p.83.

29 ibid., p.94.

30 The Queen v Recorder of Cork (1866) 16 I.C.L.R.1.

316 \& 7 Will. IV, c. 116. 
churchwardens, upon two of the principal inhabitants of the parish wherein such offence shall have been committed."

Relying on the failure of both the College and of the Board of Works to serve the prescribed notice, Cork town council refused on 9 September 1862 to admit the claim. The Commissioners of Public Works, for their part, argued that previously mandatory requirements on the serving of notices had been set aside with the adoption of the Cork Improvement Act in 1852. ${ }^{32}$ But that contention was dismissed by the council. As the applicants were entitled to do, they then appealed this initial refusal to the recorder of Cork. On 2 October the recorder, however, decided to affirm the adjudication of the town council. Immediately, the government moved a writ of certiorari returnable in the Queen's Bench to bring up the proceedings of the Cork town council to ensure that the joint application of the College and the Board to secure compensation was dealt with.

On 30 January 1863 the court of Queen's Bench unanimously dismissed the motion of the solicitor-general to have the writ of certiorari made absolute. ${ }^{33}$ No compensation was the outcome.

The judges of the Queen's Bench ${ }^{34}$ in their approach stressed the primacy of the statutory obligation to serve notice and explained the rationale behind it. There were three purposes that underlay the requirement: ${ }^{35}$

"i. the desideratum of securing compensation for the party whose property had been injured;

ii. the policy of enabling the offender to be discovered; and

iii. the need to guard the public and ratepayers against the substitution of a feigned and pretended malicious injury under the cloak of which it might be attempted to get compensation from the county for the party whose property really had not been maliciously injured, but who himself might have been the injurer of it, with a view to get a compensation for it which he could not have got in any other way."

This constituted important doctrinal clarification.

Two instances of opportunities missed by historians tackling the history of the early twentieth century can be added to this inventory.

A.T.Q. Stewart, in his seminal text The Ulster Crisis, ${ }^{36}$ includes at the outset of his survey of the constitutional and military crisis immediately preceding the outbreak of World War I an apt quotation from Thomas Hobbes's Leviathan: ${ }^{37}$

"For as the nature of Foule weather, lyeth not in a showre or two of rain; but in an inclination thereto of many dayes

3215 \& 16 Vict., c. cxliii.

33 The Queen v Recorder of Cork (1866) 16 I.C.L.R.1.

34 Lefroy C.J., Fitzgerald, O' Brien and Hayes JJ.

3516 I.C.L.R. at 13

36 The Ulster Crisis (London, 1967).

37 Hobbes, Leviathan, part I, chap.13. 
together: So the nature of War, consisteth not in actuall fighting; but in the known disposition thereto, during all the time there is no assurance to the contrary."

In the ensuing volume, space, however, has not been found to consider the ramifications of a decision of the Irish King's Bench Division handed down on 15 June 1914 and which was most certainly germane in the context of the Ulster 'crisis' (though it receives a brief mention in the appendix at page 247).

On 4 December 1913 King George V signed a royal proclamation prohibiting, under the terms of enabling customs legislation, the importation into Ireland of arms, ammunition, and the component parts of arms, empty cartridge-cases, explosives and combustibles for warlike purposes. Hunter \& Co. were gunsmiths with an address at Royal Avenue, Belfast, and they had recently placed an order for guns from Hamburg. This consignment was on its way when the proclamation was issued on 4 December.

The consignment was seized by the collector of Customs and Excise at Belfast, a Mr.Coleman, when it arrived, and Hunters sued. A jury at Belfast assizes awarded them $£ 92$ damages but the judgment entered up by Boyd J. on the strength of that verdict was set aside by a majority of the King's Bench Division (Cherry L.C.J. and Dodd J.) who held the proclamation to be constitutionally valid: Hunter \& Co. v. Coleman. ${ }^{38}$ There was a striking dissent from Kenny J. who commenced his judgment with a resounding declaration: ${ }^{39}$

"It is scarcely possible to conceive a case of greater constitutional importance than the present, involving as it does the question of the validity of a great act of State by the King in Council."

Penny Bonsall, in her book on the Irish resident magistrates, includes in her four biographical studies, an account of the career of John Charles Milling, R. M. (1873 - 1919). ${ }^{40}$ At a time when Dublin Castle was considering the transfer of Milling to do duty in Co. Antrim, he was shot and fatally wounded at his home in Co. Westport, Co. Mayo on 31 March 1919. ${ }^{41}$ Missing from Bonsall's account is any reference to one of the legal sequels to this murder: a civil bill for damages for trespass to the person and for false imprisonment brought on behalf of a boy called John McLaughlin, who had been taken into 'protective custody' as an eye-witness and kept in Castlebar for seven weeks before being finally transferred to Dublin and released. The more celebrated case of Connors v Pearson, ${ }^{42}$ where a boy had been taken into protective custody following the murder of the two policemen at Soloheadbeg, Co. Tipperary in February 1919, was held in effect to govern

[1914] 2 I.R. 372.

39 ibid., at 384.

40 Penny Bonsall, The Irish RMs: the resident magistrates in the British administration in Ireland (Dublin, n. d. [1997]), pp.134-53.

41 ibid., p.148.

42 [1921] 2 I.R. 51. 
the matter. An award in favour of Master McLaughlin for $£ 25$ was thus upheld: McLaughlin v Scott. ${ }^{43}$

Prior to the 1780s when the modern cycle of Irish law reports commences, recourse must perforce be had to English law reports for any detailed enlightenment regarding Irish affairs to be gleaned from such sources. The quest does not prove in vain. Let me furnish two discoveries.

In the summer of 1612 James I was contemplating the convening of his first Irish parliament. No Irish parliament had sat since the 1580 s and James or, at least, his advisers were uncertain as to how to proceed under the constraints set down by Poynings's Act in the reign of Henry VII. On 30 June 1612, accordingly, the lords of the English Council thus wrote to the two English chief justices, the English chief baron and the English attorney and solicitor general announcing a legal conference that was to be held to consider the interpretation of Poynings's Act 'for avoidance of any question or inconvenience arising'. Those summoned attended a two-day conference that was soon thereafter held at Serjeants' Inn in London. Coke, the chief justice of King's Bench, includes, in his law reports, the conclusions of the conference on a range of questions prompted not only by the Irish statute 10 Henry VII, c. 4 (Poynings's Act itself) but also by the important amendment passed by the Irish parliament in the middle of the sixteenth century, $3 \& 4$ Philip \& Mary, c. 4: see The Case of the Parliament in Ireland. ${ }^{44}$

The Act of Resumption passed by William III's English parliament of 1698 $99^{45}$ arranged for the vesting in trustees of estates forfeited from sundry Irish rebels. The legislation is complex as are several subsequent English statutes addressing the identical subject-matter. That the Forfeiture Trustees had overplayed their hand by seizing estates and interests that were not properly forfeited at all was confirmed in a key decision of the Irish court of King's Bench. Sadly, we know little about this decision itself, but the resultant writ of error that led to that decision being appealed to the English court of King's Bench has entailed, fortuitously, that we have the reasoning of the latter tribunal. This major case - probably something in the nature of a test case - was argued over three law terms in 1706 and 1707. Finally, early in 1707, the majority decision upholding the conclusions of the Irish King's Bench was announced: Annesley v Dixon. ${ }^{46}$ That the affair was politically sensitive was grasped by Chief Justice Holt who was to observe early on in his judgment, with which, in effect, Powell and Gould JJ. were to agree, that any construction of the Act of Resumption other than the one he had embraced 'would be, instead of quieting Ireland, the ready way to have a new war there'. ${ }^{47}$ The dissenter was Powys J. who in somewhat unguarded and highly political language appears to have warned against tinkering with what the Forfeiture Trustees had decided to do.

43 [1921] 2 I.R. 92n.

44 (1612) 12 Co. Rep. 110, 77 Eng. Rep. 1386.

45 An Act for granting an aid to his majesty by sale of the forfeited and other estates and interests in Ireland and by a land tax in England for the severall purposes therein mentioned: 11 Will. III, c. 2. For the background see J.G. Simms, The Williamite confiscation in Ireland, 1690 - 1703 (London, 1956), especially chap.2.

46 Holt K.B. 372, 90 Eng. Rep. 1106.

47 Holt K.B. at 393, 90 Eng. Rep. at 1116. 
The search programme recommended in these pages casts a significant burden on the historian and results, if and when the latter are obtained, may turn out to be disappointingly meagre. However, as I have attempted to show, that can by no means be taken for granted. Interesting discoveries are there to be made, fresh insights gained and new questions framed to be demanded of the conventional wisdom. 